\title{
High Performance Multistring Converter Topology for Three-Phase Grid Tied 200 kW Photovoltaic Generating System
}

\author{
Mohammad Rustam M.L. ${ }^{1}$, F. Danang Wijaya ${ }^{2}$
}

\begin{abstract}
Under various external conditions, grid connected PV system performance is strongly affected by the topology that is used to connect a PV system with grid. This research aims to design a multistring based converter topology for three-phase grid connected $200 \mathrm{~kW}$ PV system that has a high performance in various operating conditions. Research was done by a simulation method using Matlab-Simulink with performance being evaluated including the generated power, efficiency, power quality in accordance with grid requirements, as well as the power flow. In the simulation, multistring converter topology was designed using two dc-dc boost multistring converters connected in parallel to a centralized of three-phase three-level NPC inverter with the size of the string being shorter and more parallel strings as well as the maximum voltage of the PV array of $273.5 \mathrm{~V}$ close to dc voltage reference of $500 \mathrm{~V}$. Each dc-dc boost multistring converter have individual MPPT controllers. The simulation results showed that this multistring converter topology had a high performance in various operating conditions. This due to more power generated by the NPC inverter $(>190 \mathrm{~kW})$ at the time of high power generation on the STC conditions $\left(1000 \mathrm{~W} / \mathrm{m}^{2}, 25^{\circ} \mathrm{C}\right)$, the lowest efficiency of the total system is $95.08 \%$ and the highest efficiency of the total system is $99.4 \%$, the quality of the power generated in accordance with the requirements of grid, as well as the inverter put more active power to the grid and less reactive power to the grid. The response of the inverter slightly worse for loads with greater reactive power and unbalanced.
\end{abstract}

Keywords---PV array topology, power electronics converter topology, maximum power, efficiency, power quality, power flow.

\section{INTRODUCTION}

Environmental problems related to fossil energy and the worldwide energy crisis have never attracted so much concern as they do today. Alternative energy technologies offer us a hopeful green future. One of the most important clean energy is solar energy. This solar energy has expanded its role from the supplemental power to the alternative power [1].

With the encouragement from the worldwide governments, photovoltaic (PV) power plant has been used in three main applications, namely, satellite application where the solar arrays provide power to satellites, off-grid applications where the solar arrays are used to supply energy to remote loads that

\footnotetext{
${ }^{1}$ Department of Electrical Engineering and Information Technology, Faculty of Engineering, University of Gadjah Mada, Jl Grafika No. 2, Yogyakarta 55281, Indonesia, e-mail: rustam.latowale@mail.ugm.ac.id.

${ }^{2}$ Department of Electrical Engineering and Information Technology, Faculty of Engineering, University of Gadjah Mada, Jl Grafika No. 2, Yogyakarta 55281, Indonesia, e-mail: danangwijaya@ugm.ac.id.
}

are not connected to the grid, and on-grid or grid-connected applications where the solar arrays are used to supply energy to local loads as well as to the grid. Grid-connected PV systems currently dominate the PV market, especially in Europe, Japan and USA, where the cumulative installed PV capacity was connected to the grid having increased from $27 \%$ in 1990 to more than $90 \%$ at the end of 2007 [2]

In general, grid connected PV generating system is composed of three main components, namely, an array of PV modules, power electronics converters, and grid systems. Topology grid connected PV system is an important factor to improve the efficiency of the system [2] - [4]. Many researches have been done to improve efficiency and power quality of the PV converter since the last few decades. Those researches can be classified as new topology and new control method [5].

There are two topologies which are most often used in grid connected PV generation system such as centralized topology and distributed topology or string topology. Currently, there has been developed more recent topology and more modular topology namely multistring converter topology with two-stage power conversion. This topology is based on string topology that considers a different power conditioning topology, the arrangement of series-parallel from different PV modules, and orientation to optimize costs and to maximize systems modularity and the power generated [6]. For medium-scale to large-scale PV systems where a large number of PV module must be connected to the grid, multistring topology is preferred because string PV has various types, size, modules orientation, can be connected to a different converter [1], [7], [8]. Therefore, this multistring converter topology can be considered as an innovative solution and promising.

This research aims to design a multistring based converter topology for $200 \mathrm{~kW}$ PV system three-phase grid connected that has a high performance in various operating conditions. Research was done through a simulation method using MatlabSimulink with performance being evaluated including the generated power, efficiency, power quality according to the grid requirements, as well as the power flow. To design the multistring converter topology that has a high performance, the system was designed based on the literature study on several power electronics converter topology.

\section{ClASSIFICATION OF CONVERTER TOPOLOGY}

For all different converter topology, the energy extraction characteristics and maximum power capture capability under uniform solar irradiation are very similar. However, under shading conditions, the energy extraction characteristics strongly depends on what converter topology being used in a PV system [4]. The energy yields drop due to lower efficiency 
of the power electronics converter being estimated to range from $0.2 \%$ at the string-combiner level to $1.9 \%$ at the module level [9]. Thus, grid connected PV system must be designed in order to produce high efficiency and power quality which comply with the grid requirements under various operating conditions [3].

The converter topology for grid tied PV system can be classified according to the number of power conversion stage, location of power decoupling capacitors, transformer or transformerless, and types of grid interface [7].

\section{A. Number of Power Conversion Stage Topology}

Based on number of power conversion stage, there are two types of converter topology such two-stage converter topology which consists of dc-dc converter and dc-ac inverter, and single-stage converter topology which consists of dc-ac inverter [7], [8].

1) Two-stage Topology: Generally, the output voltage of a PV array is not high enough to be connected to the grid. Therefore, the two-stage topology can be a solution, which adding to dc-dc converter to increase the voltage as shown in Fig. 1. The main advantage of two-stage topology is the flexibility with more controllable variables, which has mean multiples control objective such as MPPT control, current flows on the grid, var compensation, active filter, and others.

2) Single-stage Topology: In two-stage topology, with the number of power conversion stage increasing, the power loss rises as well that makes all energy transferring efficiency decrease. More stage also increase the complexity of the system, thereby reduce the system reliability. To enhance system efficiency, it can be used single-stage topology that only rely on the dc-ac inverter, as shown in Fig. 2. This single-stage topology can relatively achieve higher power efficiency, but it has a more complex control methods since the inverter must handle all tasks itself, like MPPT, grid current control, a constant power factor, and perhaps voltage amplification. In addition, the inverter must be designed to handle a peak power of twice the nominal power.

From the comparative study between the two topologies shows that [8]

1. power efficiency, single-stage topology is better;

2. stability of the dc voltage and ac voltage harmonic distortion, two-stage topology is better; and

3. accuracy of the MPPT, in an acceptable error range of controller oscillation and ac filter loss, both topologies can satisfied accuracy requirements.

\section{B. Power Decoupling Capacitor Topology}

Power decoupling between the dc side and the ac side on the power electronic converter is normally achieved by means of an electrolitic capacitor or film capacitor. However, the life time of the capacitor is the main limiting factor. Thus, the capacitor size should be kept as small as possible and preferably to substitute the electrolitic capacitor with film capacitor. The capacitor is either placed in parallel with the PV modules or in the dc link between dc-dc converter and dc-ac inverter. This is as illustrated in Fig. 3 and Fig. 4 [7].

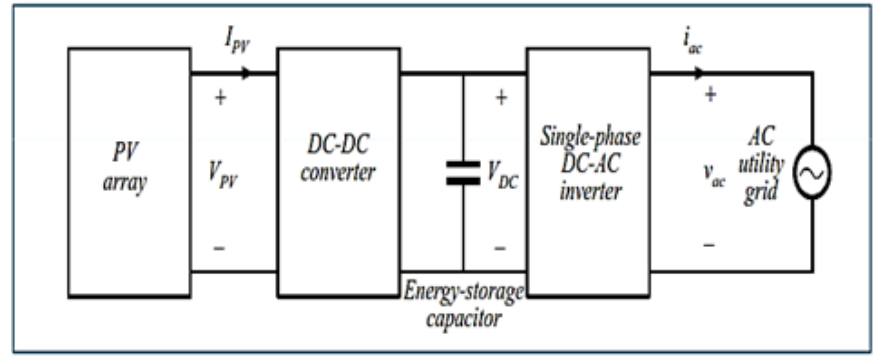

Fig. 1 Two-stage power conversion topology.

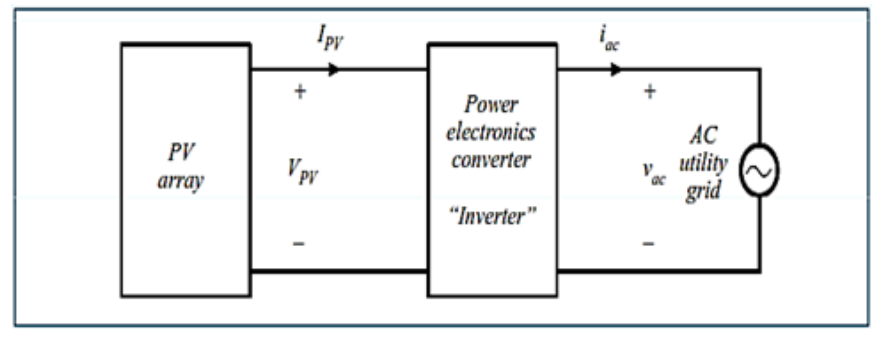

Fig. 2 Single-stage power conversion topology.

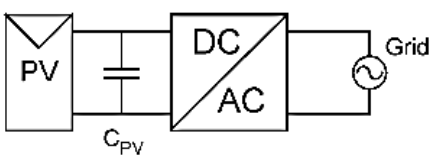

Fig. 3 Power decoupling capacitor in single-stage topology.

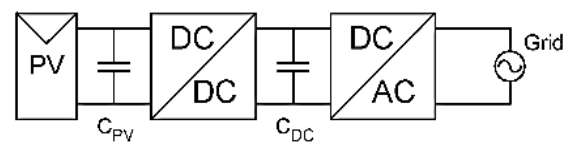

Fig. 4 Power decoupling capacitors in two-stage topology.

\section{Transformator Usage in the Converter}

Some inverters use a transformer embedded in a high frequency dc-dc converter or dc-ac inverter, others use a line frequency transformer toward the grid, and some inverters do not include a transformer at all. The line frequency transformer is regarded as a poor component due to increased size, weight, and price. While the modern converter tends to use a high frequency transformer [7].

\section{Types of grid interface}

Based on grid interface types, there are two inverter topologies that are often used, namely, current source inverter (CSI) and voltage source inverter (VSI) as shown Fig. 5 [7].

1) Current source inverter: In order to inject sinusoidal current into the grid, the inverter must be able to operate as a current source. The topology in Fig. 5(a) and Fig. 5(b) are the CSI topology. The current is modulated or controlled to follow a rectified sinusoidal waveform and the circuit is simply to re-create the sine wave and injected it into the grid. The circuits apply zero-voltage switching (ZVS) and zerocurrent switching (ZCS), thus, only conduction loss of the semiconductors remain. The converter circuit of Fig. 5(a) can be a push-pull with a single secondary transformer winding and a flyback with two secondary windings for the circuit of Fig. 5(b). 


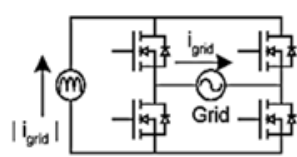

a)

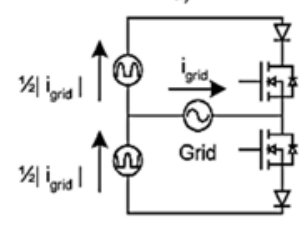

b)

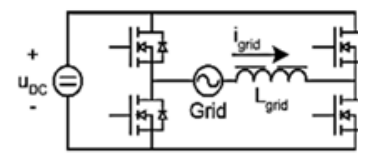

c)

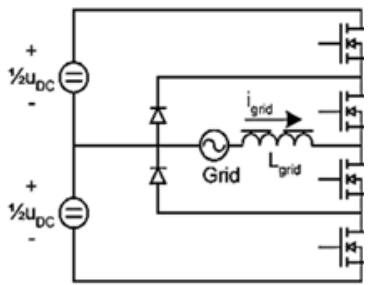

d)
Fig. 5 (a), (b) Current source inverter; (c), (d) Voltage source inverter.

The command signals for the switch transistors and the gridcurrent reference waveform are mostly based on a phaselocked loop (PLL).

2) Voltage source inverter: Fig. 5(c) is a standard fullbridge three-level VSI, which can create a sinusoidal grid current by applying positive, negative or zero voltage dc-link. It is half-bridge two-level VSI, which can only create two distinct voltages and required two dc-link voltages and two switching frequencies in order to get the same performance as the full-bridge. The topology in Fig. 5(d) is the half-bridge diode clamped three-level VSI.

\section{GRID CONNECTED PV ARRAY TOPOLOGY}

The grid connected PV array has a different topology in the connection between the PV array with the converter. The topology of grid connected PV system can affect the overall performance. The selection of the appropriate topology will help in designing a grid connected PV system. Various topology of grid connected PV system with two-stage power conversion, can be categorized into four topologies as shown in Fig. 6, as follows: centralized topology, distributed topology on the string level, distributed topology on the multistring level, and distributed topology on the module level. There is also a new topology that has been developed, namely split multistring and dual multistring topology which is a development from the multistring based topology [9], [10].

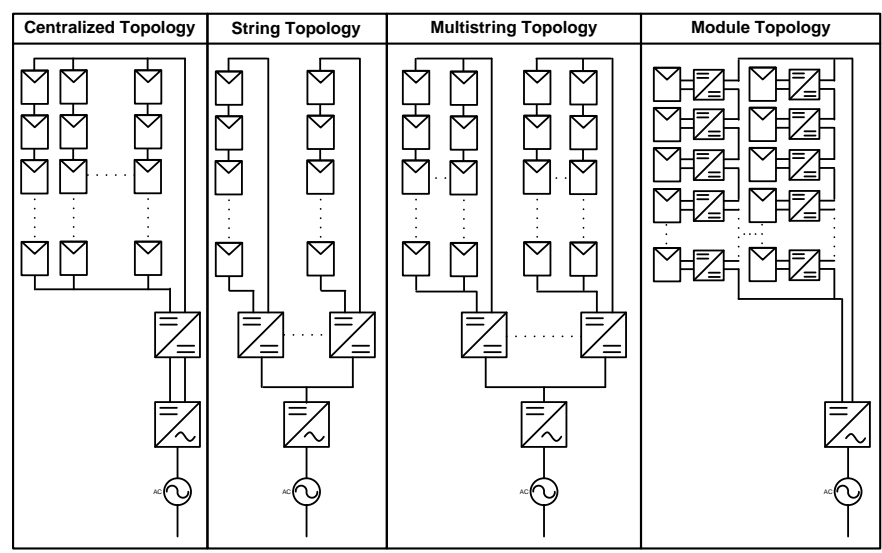

Fig. 6 Topology of grid connected PV array, two-stage power conversion.
The distributed topology has some advantages compared to centralized topology because it can produce higher energy, more flexible in design, and can be applied both for mediumscale and large-scale PV plant with higher power quality and easy to monitor and analyze in case of damage or system failure [9].

In a distributed topology with two-stage power conversion, each dc-dc converter has individual MPPT controller, so that it can improve energy yield significantly. For large-scale PV plant with a relatively large number of parallel string for each dc-dc converter provide a high energy yield. Whereas, for large-scale PV plant with more series connected PV module or a relatively small number of parallel string for each dc-dc converter. It's performance become more sensitive to various operating conditions. Therefore, a significant increase in energy yield can be obtained through string level distribution of the dc-dc converters or multistring distribution with a small number of strings connected to each converter. Multistring topology can be designed modular, where some of string from the PV module with a different orientation and types can be connected to one of the dc-dc converter [9].

\section{COMPARISON OF DC-DC CONVERTER TOPOLOGIES}

Energy yield and cost analysis of large scale PV power plant led to the conclusion that for PV power plant that was built using a high power and low voltage modules, the use of a string level dc-dc power converters topology will provide the optimum benefit point. Whereas, for PV power plant that was build using a high voltage and low power modules, the use of a multistring level dc-dc power converters topology will provide the optimum benefit point. Therefore, it is necessary to identify the best dc-dc converter in the aspect of design, operation and control for the string or multistring inputs. Converter size, cost and ease of system integration are also key factors in the selection process.

In the transformerless converter topology, the dc-dc boost converter is the best solution because of low part number of components and simpler design. However, it has disadvantages at operating voltage range $800-1,200 \mathrm{~V}$ where usually using the relatively low switching frequency, and consequently a large input inductor. In addition, it can not meet the efficiency requirements without adding auxiliary circuit for soft switching operations [6]. The basic topology of dc-dc boost converter is shown on Fig. 7.

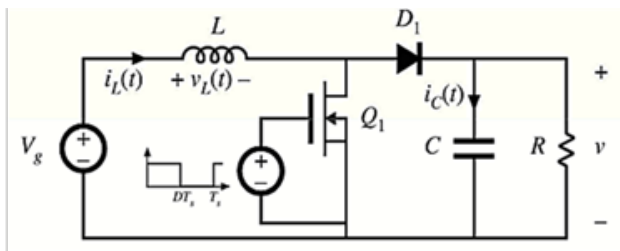

Fig. 7 Topology of the dc-dc boost converter.

To solve the problem of low switching frequency, a threelevel dc-dc boost converter topology can be used. Since the voltage stress on the switches is half the output voltage, high switching frequency operation and compact size can be achieved by using low voltage MOSFET (400V-600V). 
Efficiency can also be improved by operating the inductor in critical conduction mode [6].

In high frequency transformer topology, the full-bridge dcdc converter is the most used isolated topology, both as CSI or VSI. However, due to the added components (four switches, isolation transformer, and rectifier) lead to reduce reliability, lower power density and higher cost. To increase its efficiency, the dc-dc full-bridge converter with partial power processing can be used, where only a partial of the generated power in the PV string flows through the full-bridge converter and the remaining power is directly fed forward to the output of the converter. However, this mode of operation leads to the loss of the benefit of the converter being an isolated topology [6].

Isolation transformer facilitates the parallel connection of multiple inverter, since non-isolated topologies require the inverters to be isolated in order be operated in parallel, which requires the use of large power line medium voltage transformers. The use of the dc-dc converter as a replacement for the isolated transformer will reduce the size of inverter and cost savings.

In the distributed dc-dc converter topology, each dc-dc converter can be connected each other, both in series or in parallel. In series connection, each converter connected in series with other converter before being connected to the dclink. This can lead to the imbalance of output voltage between each converter and over voltage in each converter. Whereas, in parallel connection does not has a problem with it, since each the output converter connected in parallel directly to the dclinks [5]. The selection of dc-dc converter topology also depends on the number of PV modules connected to the dc-dc converters and the bus-dc voltage [11].

\section{COMPARISON OF DC-AC INVERTER TOPOLOGIES}

\section{A. Conventional dc-ac Inverter Topology}

The conventional dc-ac inverter ussualy use $\mathrm{H}$ bridge topology as shown in Fig. 8. It can produce two output voltage levels (+/- $V_{d c}$ and 0$)$ [12].
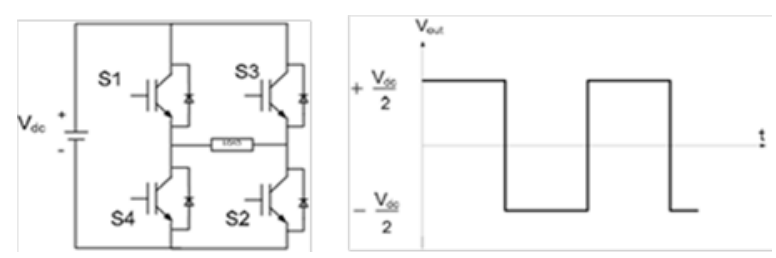

Fig. 8 Conventional dc-ac inverter using H-bridge topology.

\section{B. Multilevel dc-ac Inverter Topology}

The multilevel dc-ac inverter topology has several advantages compared to conventional two-level dc-ac inverter topology. This multilevel inverter topology has the ability to generate higher output voltage, reducing the harmonic content, lower switching losses, and higher fundamental amplitude. However, it has some drawbacks, include voltage unbalance difficulties, unequal current stresses, and higher implementation costs [13].

As the number of output voltage level of the multilevel inverter reaches infinity, the THD output approaches zero.
However, the number of the achieveable voltage level is limited by the problem of voltage imbalance, voltage clamping requirements, circuit layout, and packaging constraints complexity of the controller, as well as capital and maintenance costs.

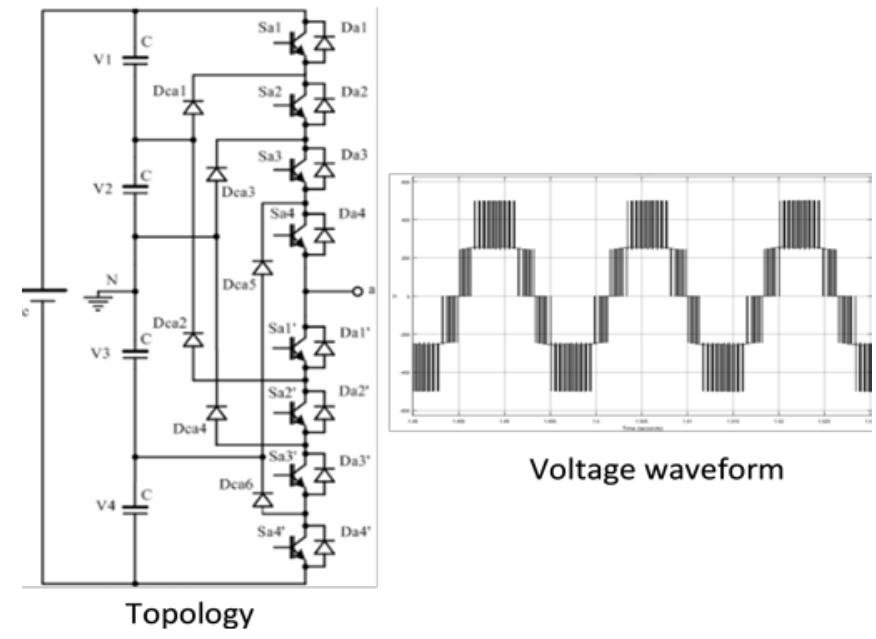

Fig. 9 Topology and output voltage of single-phase three-level NPC inverter.

There are three multilevel inverter topologies such as neutral-point-clamped (NPC) or diode-point-clamped, flyingcapacitor, and cascaded H-bridge multilevel inverter [2]. The NPC inverter topology generates a multilevel voltage following sinusoidal waveform at its output by connecting in series a number of semiconductor switches within the inverter, with output voltage level set by the diode. Every NPC cell in this topology is connected to the same dc source. It is different with the cascaded H-bridge topology that has different dc source for every cell. Fig. 9 shows the single-phase NPC inverter topology that generates three output voltage level $(+/-$ Vdc, +/- 1/2 Vdc, 0) [13].

\section{The SELECTION OF GRID CONNECTED PV SYSTEM TOPOLOGY}

Based on the literature study on the comparison of various converter topology in grid connected PV system, the selected topology in this research is as follows.

1. Distributed topology on the multistring level to improve the energy yield under various operating conditions.

2. The topology of the two-stage power conversion for ease in designing of control method as well as to obtain a higher and stable dc voltage for inverter.

3. The power decoupling capacitor is placed in the dc bus between the dc-dc converter and dc-ac inverter, with small capacitor size.

4. Transformerless topology using the dc-dc boost converter to reduce the inverter size and costs.

5. VSI using three-phase three-level NPC topology to reduce harmonic content.

6. Dc-dc boost converter topology to increase the natural PV array voltage to the voltage level that can interact with the grid (in operating voltage range 250 - $500 \mathrm{~V}$ ).

7. Distributed dc-dc boost converter topology on multistring level with the shorter string size or relatively large number 
of parallel string making the system performance being not sensitive to the various operating conditions.

\section{The Design Of Simulation}

The simulation design was made in accordance to the selected topology as follows.

1. The PV module is SunPower $305 \mathrm{Wp}$, with characteristic is shown in Table I [14].

TABLE I

DATA SHEET OF SUNPOWER 305 WP PV MODULE

\begin{tabular}{|l|l|}
\hline \multicolumn{1}{|c|}{ Electrical Data } & \multicolumn{1}{c|}{ Value } \\
\hline A. Performance under standard test conditions (STC) \\
\hline Maximum power, PMPP & $305 \mathrm{Wp}$ \\
\hline Open circuit voltage, VoC & $64.2 \mathrm{~V}$ \\
\hline Maximum power point voltage, VMPP & $54.7 \mathrm{~V}$ \\
\hline Short circuit current, Isc & $5.96 \mathrm{~A}$ \\
\hline Maximum power point current, IMPP & $5.58 \mathrm{~A}$ \\
\hline B. Component materials & 96 \\
\hline Cell per module & Mono Crystalline \\
\hline Cell type & 3 \\
\hline Bypass diode &
\end{tabular}

2. PV power plant, $200 \mathrm{~kW}$, consists of 660 units $305 \mathrm{Wp} \mathrm{PV}$ module, is divided into PV array 1 and PV array 2. Each array consists of 330 units PV module and $100 \mathrm{~kW}$ maximum power on STC.

3. Each PV array arranged in parallel-series configuration, with five units PV module connected in series per string and 66 unit string connected in parallel to generate $500 \mathrm{Vdc}$. This configuration is selected so that the maximum string voltage can obtaine dc voltage reference, so that the effort to increase the PV voltage is not too large $\left(V_{M P P}=5 \times 54.7 \mathrm{~V}=\right.$ $273.5 \mathrm{~V})$.

4. Two units of the dc-dc boost multistring converter and a three-phase three-level NPC inverter are used. Each $\mathrm{PV}$ array is connected to a dc-dc boost converter that has an individual MPPT control.

5. The dc-dc boost converter is functioned to increase the natural voltage of PV array to reference voltage $500 \mathrm{Vdc}$, and also to regulate the PV array voltage to obtain the maximum power with regulate automatically the duty cycle of the IGBT component. Duty cycle of the IGBT components is done through the MPPT controller using incremental conductance technique, with initial duty cycle is set to 0.5 .

6. A three-phase three-level NPC inverter functioned to convert the voltage $500 \mathrm{Vdc}$ on dc bus to 260 Vac with low THD voltage, and to generate the instantaneous current inverter with a small ripple in phase to instantaneous voltage grid.

7. Two capacitors $(12 \mathrm{mF})$ are connected in series on the dc bus.

8. The RL filter is functioned to reduce harmonic contain before connected to grid through a three-phase transformer $260 \mathrm{~V} / 25 \mathrm{kV} 60 \mathrm{~Hz} 400 \mathrm{kVA}$. A series filter without capacitor is intended to minimize reactive power that is injected into the grid. The three-phase load system is applied with three-phase parallel RLC load.
9. The irradiance and temperature variation is applied on each $\mathrm{PV}$ array, which is designed using the signal generator.

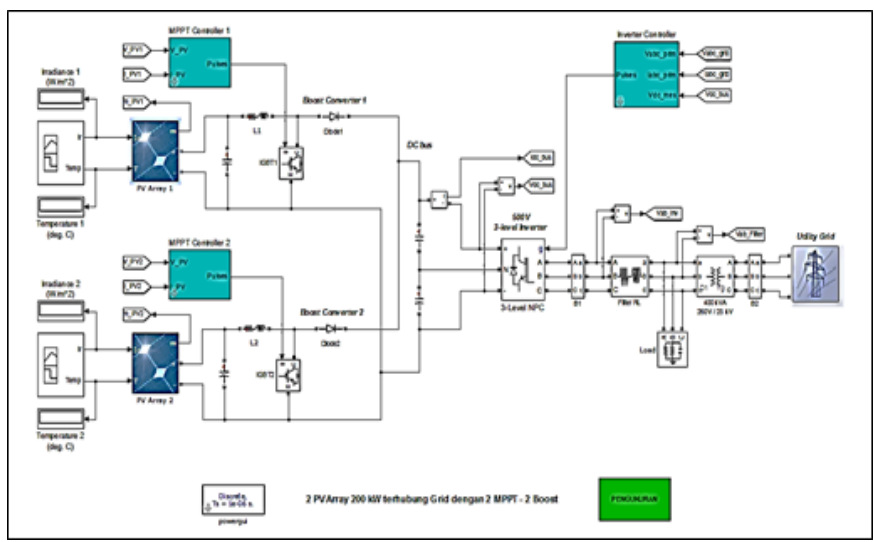

Fig. 10 Simulation design of three-phase grid connected multistring converte topology.

Fig. 10 shows the simulation design of three-phase grid connected multistring topology. The PV array is designed using the PV array block in Matlab-Simulink library. The various operating conditions is done through different irradiance, temperature and load conditions. Different irradiance and temperature is applied to PV array 1 and 2 as shown in Table II.

The simulation of irradiance and temperature variation from the STC irradiance $1,000 \mathrm{~W} / \mathrm{m}^{2}, 25^{\circ} \mathrm{C}$ to $1,000 \mathrm{~W} / \mathrm{m}^{2}, 50{ }^{\circ} \mathrm{C}$ is represented the high to low power generation. Two different loads which have various types of load, number of load and unbalance load factor as shown and simulated in the Table III. The measurement design was done by measuring the voltage and the current of PV array, dc-dc boost converter, dc bus, NPC inverter, and bus grid, as well as the current THD and voltage THD at the inverter output and grid. It also observes the duty cycle of dc-dc boost converter, MPPT controller performance and the behavior of the inverter.

TABLE II

SIMULATION DESIGN OF IRRADIANCE AND TEMPERATURE

\begin{tabular}{|c|c|c|c|c|c|c|c|c|}
\hline \multirow{2}{*}{ No } & \multicolumn{3}{|c|}{ PV Array 1 / MPPT1 } & \multicolumn{3}{c|}{ PV Array 2 / MPPT2 } \\
\cline { 2 - 9 } & $\begin{array}{c}\text { Modul/ } \\
\text { String }\end{array}$ & $\begin{array}{c}\text { String } \\
\text { Paralel }\end{array}$ & $\begin{array}{c}\text { Irr. } \\
\left(\mathbf{W} / \mathbf{m}^{2}\right)\end{array}$ & $\begin{array}{c}\text { T } \\
\left({ }^{\mathbf{0}} \mathbf{C}\right)\end{array}$ & $\begin{array}{c}\text { Modul/ } \\
\text { String }\end{array}$ & $\begin{array}{c}\text { String } \\
\text { Paralel }\end{array}$ & $\begin{array}{c}\text { Irr. } \\
(\mathbf{W} / \mathbf{m} 2)\end{array}$ & $\begin{array}{c}\text { T } \\
\left({ }^{\mathbf{0}} \mathbf{C}\right)\end{array}$ \\
\hline 1 & 5 & 66 & 1,000 & 25 & 5 & 66 & 1,000 & 25 \\
\hline 2 & 5 & 66 & 800 & 25 & 5 & 66 & 600 & 25 \\
\hline 3 & 5 & 66 & 400 & 25 & 5 & 66 & 200 & 25 \\
\hline 4 & 5 & 66 & 800 & 35 & 5 & 66 & 800 & 35 \\
\hline 5 & 5 & 66 & 950 & 45 & 5 & 66 & 1,000 & 50 \\
\hline 6 & 5 & 66 & 1,000 & 50 & 5 & 66 & 1,000 & 50 \\
\hline
\end{tabular}

TABLE III

SiMUlATION DESIGN OF THREE-PHASE LOAD SIMULATION

\begin{tabular}{|c|c|c|c|c|c|c|c|c|c|c|c|c|}
\hline \multirow{2}{*}{ No } & \multicolumn{3}{|c|}{$\begin{array}{c}\text { P } \\
\text { kW }\end{array}$} & \multicolumn{3}{c|}{$\begin{array}{c}\text { QL } \\
\text { Kvar }\end{array}$} & \multicolumn{3}{c|}{$\begin{array}{c}\text { QC } \\
\text { Kvar }\end{array}$} & $\begin{array}{c}\text { P } \\
\text { kW }\end{array}$ & $\begin{array}{c}\text { Q } \\
\text { kvar }\end{array}$ & $\begin{array}{c}\text { S } \\
\text { kVA }\end{array}$ \\
\cline { 2 - 14 } & A & B & C & A & B & C & a & b & C & Tot & Tot & Tot \\
\hline 1 & 10 & 10 & 10 & 4 & 4 & 4 & 0 & 0 & 0 & 30 & 12 & 32 \\
\hline 2 & 30 & 32 & 28 & 15 & 17 & 13 & 5 & 7 & 3 & 90 & 30 & 95 \\
\hline
\end{tabular}




\section{Simulation Results AND DisCUSSION}

\section{A. The Performance of PV Array}

The performance of PV array 1 and PV array 2 under various irradiance and temperature conditions on load simulation 1 is shown in the Fig. 11. It can be seen that at lower irradiance $\left(\mathrm{W} / \mathrm{m}^{2}\right)$, the $\mathrm{PV}$ array current will be progressively decrease and the PV array voltage will lower so that the power generation will decrease. When temperatures increased, the voltage of PV array will decrease, so that the power generation will also decrease.
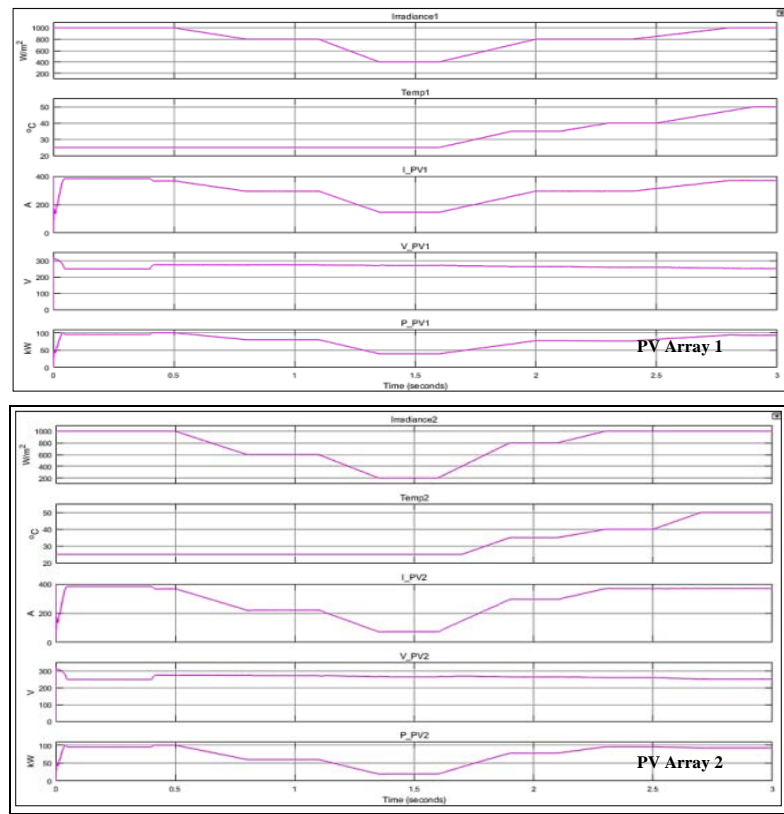

Fig. 11 Performance of PV array on load simulation 1.

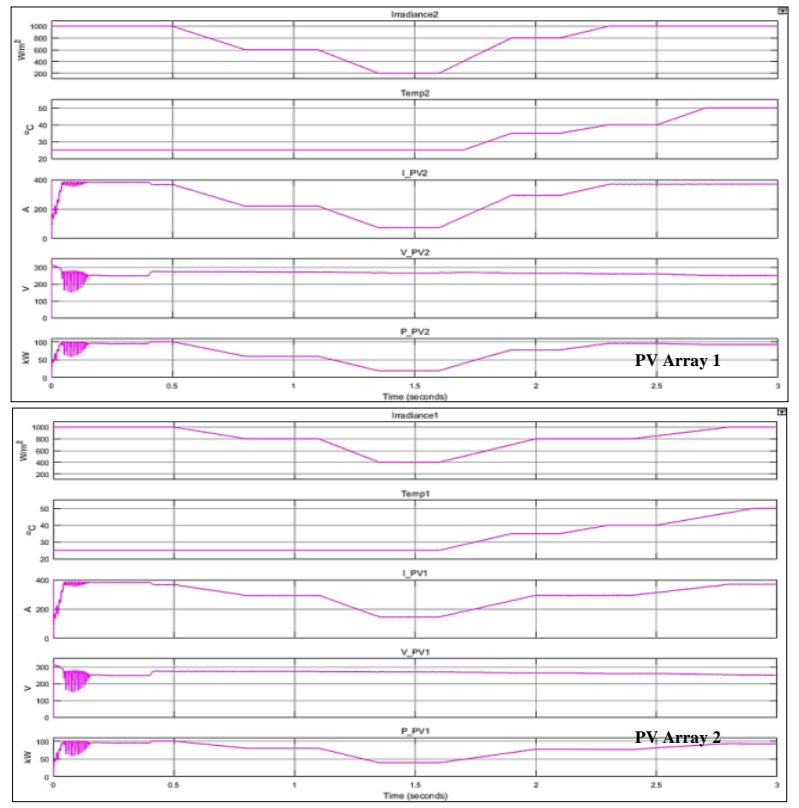

Fig. 12 Performance of PV array on load simulation 2.

On load simulation 2, they have similar performance, but there is distorted voltage at the beginning of the simulation seen on PV array. The steady state reached a little longer than the load simulation 1 as shown in the Fig. 12.

\section{B. The Performance of the dc-dc Boost Multistring Converter}

In this simulation, dc-dc boost converter increased natural PV array voltage to the reference voltage of $500 \mathrm{Vdc}$ and obtained maximum power point of the PV array in various operating conditions. The increment of voltage was done by regulating the duty cycle on the IGBT components. MPPT was done by the MPPT controller using the incremental conductance algorithm. The simulation resulted in regulating the duty cycle both the dc-dc boost converter ( $D 1$ and $D 2)$ to increase the voltage on load simulation 1 and load simulation 2, respectively are shown in Table IV and Table V.

TABLE IV

DUTY CyClE OF DC-DC BOOST CONVERTER, LOAD SIMULATION 1

\begin{tabular}{|c|c|c|c|c|c|c|c|c|c|c|c|}
\hline Ir & \multirow{2}{*}{$\begin{array}{l}\text { Vi1 } \\
\text { T }\end{array}$} & \multirow{2}{*}{ D1 } & Vo1 & \multirow{2}{*}{ Vi2 } & \multirow{2}{*}{ D2 } & Vo2 & Ii1 & \multirow{2}{*}{ Io1 } & Ii2 & Io2 & $\begin{array}{c}\text { Vdc } \\
\text { bus }\end{array}$ \\
\cline { 8 - 12 } & & $\mathbf{V}$ & $\mathbf{V}$ & & $\mathbf{V}$ & $\mathbf{A}$ & $\mathbf{A}$ & $\mathbf{A}$ & $\mathbf{A}$ & $\mathbf{V}$ \\
\hline 1 & 249.3 & 0.45 & 499.0 & 249.3 & 0.45 & 499.0 & 381.8 & 199.8 & 381.8 & 199.8 & 499.9 \\
\hline 2 & 274.0 & 0.45 & 495.6 & 272.9 & 0.46 & 498.8 & 292.5 & 160.9 & 219.3 & 119.5 & 500.0 \\
\hline 3 & 270.7 & 0.46 & 496.5 & 265.3 & 0.47 & 495.3 & 146.0 & 79.4 & 72.9 & 39.0 & 499.9 \\
\hline 4 & 265.0 & 0.47 & 502.0 & 264.2 & 0.47 & 498.7 & 293.3 & 154.0 & 294.4 & 155.1 & 500.3 \\
\hline 5 & 257.9 & 0.49 & 498.1 & 256.7 & 0.50 & 495.8 & 331.9 & 178.7 & 367.8 & 186.0 & 500.1 \\
\hline 6 & 251.5 & 0.50 & 499.2 & 251.0 & 0.50 & 498.3 & 369.4 & 184.7 & 370.1 & 185.1 & 500.0 \\
\hline
\end{tabular}

TABLE V

DUTY CYCLE OF DC-DC BOOST CONVERTER, LOAD SIMULATION 2

\begin{tabular}{|c|c|c|c|c|c|c|c|c|c|c|c|}
\hline & Vi1 & D & $\mathbf{V}_{t}$ & Vi2 & & Vo2 & Ji1 & Io1 & Ii2 & Io2 & dc \\
\hline & V & & $\mathbf{V}$ & V & & V & A & $\mathbf{A}$ & $\mathbf{A}$ & $\mathbf{A}$ & $\mathbf{V}$ \\
\hline 1 & 49 & & & 8 & & & & & & & \\
\hline 2 & 73 & & & & & & & & & & \\
\hline 3 & 70 & & & & & & & & & & \\
\hline 4 & & & & & & & & & & & \\
\hline 5 & & & & & & & & & & & \\
\hline & & & & & & & & & 369. & 184. & 490 \\
\hline
\end{tabular}

From Table IV, the duty cycle on the dc-dc boost converter (D1 and D2) looks slightly different to improve the different input voltage at the same voltage level on the dc bus $500 \mathrm{~V}$. The second duty cycle was set from 0.45 to 0.50 under various irradiance and temperatures conditions. Input voltage of dc-dc boost converter, $V_{g}$, enhanced by a conversion ratio, $M$, to produce output voltage, $V$, as stated in (1).

$$
V=M \cdot V_{g}=\frac{1}{(1-D)} \cdot V_{g}
$$

where $D$ is the duty cycle. With the same duty cycle, input current of dc-dc boost converter, $I_{g}$, revealed to produce the output current, $I$, which is stated in (2).

$$
I=\frac{1}{M} \cdot I_{g}=(1-D) \cdot I_{g} \text {. }
$$

Table V shows that the dc bus voltage is more stable around $500 \mathrm{~V}$. The performance of both dc-dc boost multistring converters to obtain the maximum power of PV array in load simulation 1 and 2 are shown in Fig. 13 and Fig. 14.

In Fig. 13, from $t=0 \mathrm{~s}$ to $\mathrm{t}=0.05 \mathrm{~s}$, both duty cycle are not active, and the voltage of both PV array is open circuit voltage (VoC) of $321 \mathrm{~V}$ (Nseri $\times \mathrm{VoC}=5 \times 64.2 \mathrm{~V}$ ). When $\mathrm{t}=0.05 \mathrm{~s}$ 
both duty cycle start to regulate at the initial duty cycle of 0.5. The steady state is reached when $t=0.069$ seconds, so that both $\mathrm{PV}$ array voltage decreased from VoC to operating voltage of $250 \mathrm{~V} \quad((1-D) \quad \times$ Vbus- $d c=(1-0.5) \quad$ x 500 V). When the irradiance and temperature conditions for both PV array is $1,000 \mathrm{~W} / \mathrm{m}^{2}$ and $25^{\circ} \mathrm{C}$, the total power of both the dc-dc boost converter is $192 \mathrm{~kW}$ which is lower than maximum power $\left(P_{M P P}\right)$ of $201.4 \mathrm{~kW}$ in the same conditions.

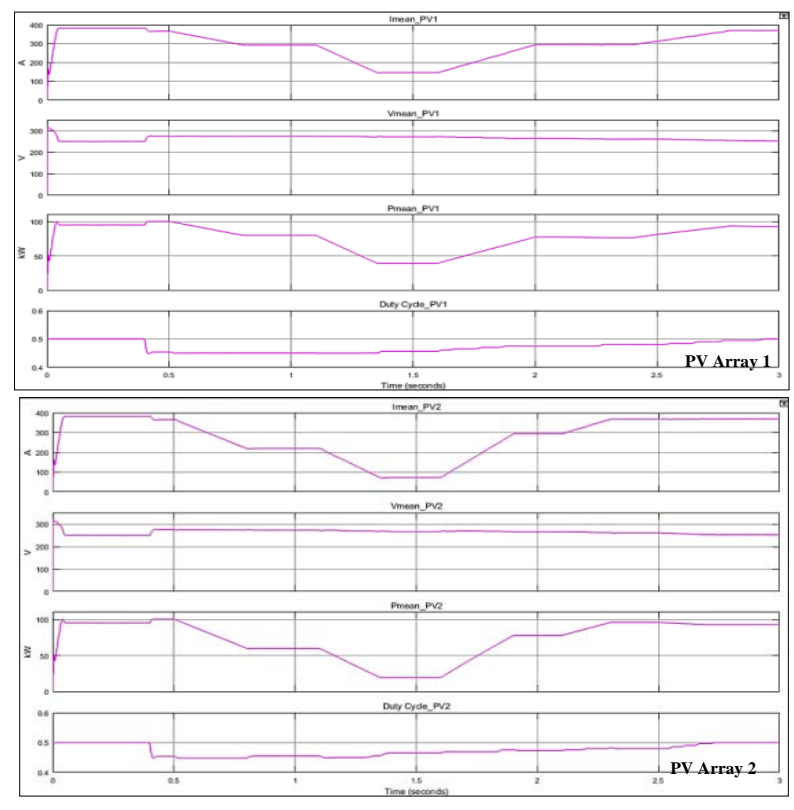

Fig. 13 Performance of dc-dc boost converter on load simulation 1.

When $\mathrm{t}=0.4 \mathrm{~s}$, MPPT controller begin to actively set the second voltage PV array by changing both duty cycles in order to obtain maximum power. At the time, both duty cycles are regulated at 0.45 , and the second voltage PV array increased from operating voltage $250 \mathrm{~V}$ to the maximum voltage $273 \mathrm{~V}$, so that the total maximum power of both dc-dc boost converter is at $199.4 \mathrm{~kW}$ until $\mathrm{t}=0.5 \mathrm{~s}$.

In Fig. 14, when $t=0.5 \mathrm{~s}$ to $\mathrm{t}=0.8 \mathrm{~s}$, where the irradiance of PV array 1 decreased from $1,000 \mathrm{~W} / \mathrm{m}^{2}$ to $800 \mathrm{~W} / \mathrm{m}^{2}$ and irradiance PV array 2 decreased from $1,000 \mathrm{~W} / \mathrm{m}^{2}$ to 600 $\mathrm{W} / \mathrm{m}^{2}$ at $25{ }^{\circ} \mathrm{C}$, MPPT control continued tracking the maximum power. When the low power increased at $t=1.5 \mathrm{~s}$, where the irradiance PV array 1 decreased from $800 \mathrm{~W} / \mathrm{m}^{2}$ to $400 \mathrm{~W} / \mathrm{m}^{2}$ and irradiance PV array 2 decreased from $600 \mathrm{~W} / \mathrm{m}^{2}$ to $200 \mathrm{~W} / \mathrm{m}^{2}$ with temperature remains $25{ }^{\circ} \mathrm{C}$, MPPT control system continued to track the maximum power. At the time, duty cycle 1 regulated by 0.46 and duty cycle 2 regulated by 0.47 , the total power both the dc-dc boost converters remain at maximum power of $58.7 \mathrm{~kW}$. At $\mathrm{t}=3 \mathrm{~s}$, the irradiance both PV array back to $1,000 \mathrm{~W} / \mathrm{m}^{2}$ and temperature $50{ }^{\circ} \mathrm{C}$, both duty cycles were set as 0.5 . At the time of the second voltage PV array fell down to $251 \mathrm{~V}$, so that the total maximum power both dc-dc boost converters was obtained by $184.4 \mathrm{~kW}$. It was lower than the maximum power on the STC conditions. The load simulation 2 also showed the relatively similar performance, but at the beginning simulation seen second voltage PV array distorted, so that the steady state condition was reached a little longer than the load simulation 1.

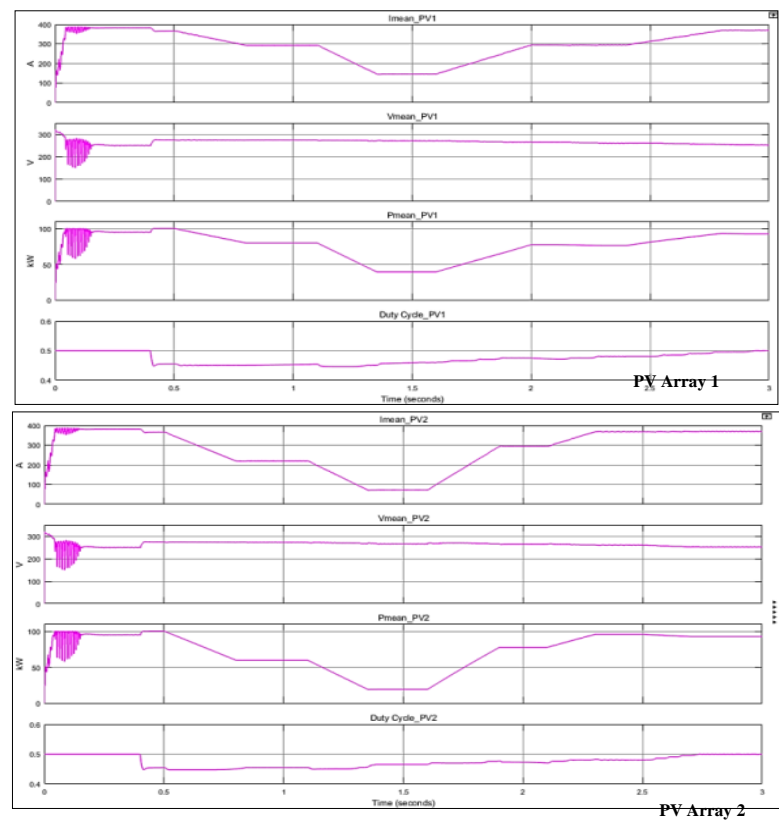

Fig. 14 Performance of dc-dc boost converter on load simulation 2.

Simulation results of the MPPT controller performance to obtain maximum power in load simulation 1 and load simulation 2, respectively are shown in Fig. 15 and Fig. 16. The second maximum power PV array in various operating conditions were obtained by applying individual MPPT control system using the technique of incremental conductance algorithm on each dc-dc boost converter. In this technique, maximum power was obtained when variation conductance exodus with negative conductance [8], as stated in (3).

$$
\frac{d I}{d V}=-\frac{I}{V}
$$

From Fig. 16, the MPPT on both the dc-dc boost converter shows that both MPPT start active at $\mathrm{t}=0.4 \mathrm{~s}$, where at the time variation of conductance start with negative conductance. After $\mathrm{t}=0.4 \mathrm{~s}$ until $\mathrm{t}=3 \mathrm{~s}$, variation of conductance always synchron with the negative conductance in various irradiance and temperature conditions. Therefore both PV array always get maximum power. The load simulation 2 also has a similar MPPT performance, but at the beginning of simulation because of negative conductance there is a distortion. The steady state condition is reached a little longer than the load simulation 1. This of course can affect the amount of energy produced.

\section{The Power, System Efficiencies, and Power Flow}

To evaluate the power produced by the PV array $\left(P_{p v}\right)$, power produced by the dc-dc boost converter $\left(P_{\text {boost }}\right)$, the total active power $\left(P_{\text {inv }}\right)$ and total reactive power $\left(Q_{\text {inv }}\right)$ which are produced by the three phase NPC inverter board and the total three phases active power $\left(P_{\text {grid }}\right)$ and total reactive power $\left(Q_{\text {grid }}\right)$ on the bus grid are calculated using $(4)-(7)$ [11].

$$
\begin{aligned}
& P_{p v}=V_{p v} \times I_{p v} \\
& P_{\text {boost }}=V_{\text {out_boost }} \times I_{\text {out_boost }}
\end{aligned}
$$




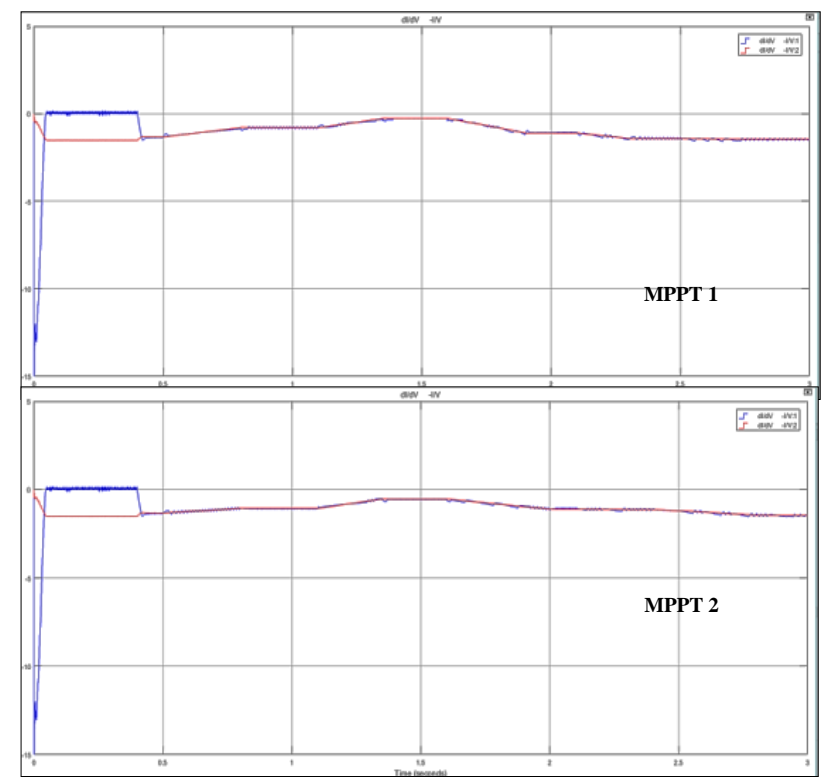

Fig. 15 Performance of MPPT controller on load simulation 1.
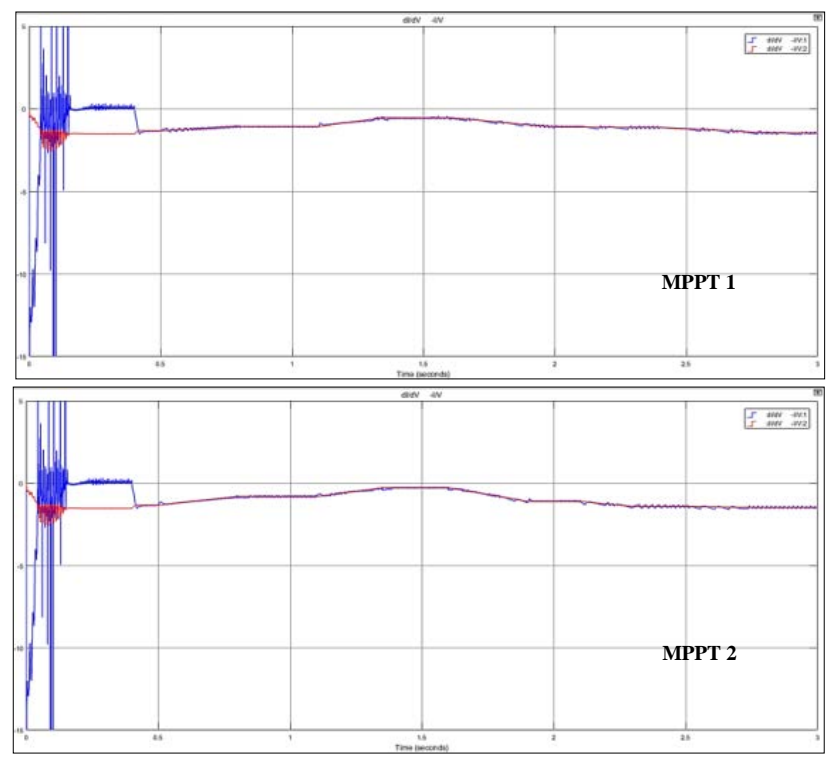

Fig. 16 Performance of MPPT controller on load simulation 2.

$$
\begin{aligned}
& P_{\text {inv }}=\sqrt{3} \cdot V_{L} \cdot I_{L} \cos \emptyset, \quad Q_{i n v}=\sqrt{3} \cdot V_{L} \cdot I_{L} \sin \emptyset \\
& P_{\text {grid }}=\sqrt{3} \cdot V_{L} \cdot I_{L} \cos \emptyset, \quad Q_{\text {grid }}=\sqrt{3} \cdot V_{L} \cdot I_{L} \sin \emptyset
\end{aligned}
$$

Based on the power that is produced by each system converter PV, the efficiency of the dc-dc boost converter $\left(\eta_{\text {boost }}\right)$, efficiency of inverter NPC $\left(\eta_{\text {inv }}\right)$, and the efficiency of the total system $\left(\eta_{t o t}\right)$ can be calculated using (8) - (10) [11].

$$
\begin{aligned}
& \eta_{\text {boost }}=\frac{P_{\text {boost }}}{P_{P V}} \times 100 \% \\
& \eta_{\text {inv }}=\frac{P_{\text {inv }}}{P_{\text {boost }}} \times 100 \% \\
& \eta_{\text {tot }}=\eta_{\text {boost }} \times \eta_{i n v}
\end{aligned}
$$

The load power will be served by PV system and grid. This will affect the direction of the power flow. If the power produced by the PV system is greater than the load power, then the converter will give the excess power to the grid. On the contrary, if the power produced by the PV system is less than the load power, then the converter will absorb the additional power from the grid. This power flow direction will determine the amount of active power and reactive power given to the grid $(P+$ and $Q+)$, or absorbed from the grid ( $P$ - and $Q-)$. The impact of the connection of the PV system into the grid influenced by the greatness of the active and reactive power given to the grid. Where the more active power given to the grid $(P+)$ and the less reactive power given to the grid $\left(Q^{+}\right)$, then the performance of the grid will be the better [15].

The power produced by the PV array, dc-dc boost converter, NPC inverter, and power is injected into the grid or absorbed from the grid in the load simulation 1 and 2 are presented on Table VI and Table VII.

TABLE VI

THE POWER OF THREE-PHASE GRID CONNECTED PV SYSTEM, LOAD SIMULATION 1

\begin{tabular}{|c|c|c|c|c|c|c|c|c|c|c|}
\hline $\begin{array}{l}\text { Ir } \\
\&\end{array}$ & $\begin{array}{c}\text { P } \\
\text { PV1 }\end{array}$ & \begin{tabular}{|c|} 
P \\
PV2
\end{tabular} & \begin{tabular}{|c|} 
P tot \\
PV
\end{tabular} & $\begin{array}{c}P \\
\text { boost1 }\end{array}$ & $\begin{array}{c}\mathbf{P} \\
\text { boost2 }\end{array}$ & $\begin{array}{l}\text { P tot } \\
\text { boost }\end{array}$ & $\begin{array}{c}\mathbf{P} \\
\text { Inv }\end{array}$ & $\begin{array}{c}\text { Q } \\
\text { Inv }\end{array}$ & $\begin{array}{c}\mathbf{P} \\
\text { Grid }\end{array}$ & $\begin{array}{c}\mathbf{Q} \\
\text { Grid }\end{array}$ \\
\hline $\mathbf{T}$ & $\mathbf{k W}$ & $\mathbf{k W}$ & $\mathbf{k W}$ & kW & kW & kW & kW & Kvar & $\mathbf{k W}$ & Kvar \\
\hline 1 & 100.4 & 100.4 & 200.8 & 99.7 & 99.7 & 199.4 & 192.1 & 83.7 & 101.3 & -0.12 \\
\hline 2 & 80.2 & 59.9 & \begin{tabular}{|l}
140.1 \\
\end{tabular} & 79.7 & 59.6 & \begin{tabular}{|l}
139.3 \\
\end{tabular} & \begin{tabular}{|l}
138.1 \\
\end{tabular} & 56.2 & 52.2 & 0.03 \\
\hline 3 & 39.5 & 19.4 & 58.9 & 39.4 & 19.3 & 58.7 & 58.6 & 33.5 & -27.7 & -0.03 \\
\hline 4 & 77.8 & 77.8 & 155.6 & 77.3 & 77.4 & 154.7 & 153.1 & 61.4 & 66.0 & 0.12 \\
\hline 5 & 89.7 & 92.9 & 182.6 & 89.0 & 92.2 & 181.2 & 180.1 & 74.3 & 90.6 & -0.08 \\
\hline 6 & 92.9 & 92.9 & 185.8 & 92.2 & 92.2 & 184.4 & 183.8 & 78.6 & 96.6 & 0.02 \\
\hline
\end{tabular}

\begin{tabular}{|c|c|c|c|c|c|c|c|c|c|c|}
\hline $\begin{array}{c}\text { Ir } \\
\&\end{array}$ & $\begin{array}{c}\text { P } \\
\text { PV1 }\end{array}$ & $\begin{array}{c}\text { P } \\
\text { PV2 }\end{array}$ & $\begin{array}{c}\text { P tot } \\
\text { PV }\end{array}$ & $\begin{array}{c}\text { P } \\
\text { boost1 }\end{array}$ & $\begin{array}{c}\text { P } \\
\text { boost2 }\end{array}$ & $\begin{array}{c}\text { P tot } \\
\text { boost }\end{array}$ & $\begin{array}{c}\text { P } \\
\text { Inv }\end{array}$ & $\begin{array}{c}\text { Q } \\
\text { Inv }\end{array}$ & $\begin{array}{c}\text { P } \\
\text { Grid }\end{array}$ & $\begin{array}{c}\mathbf{Q} \\
\text { Grid }\end{array}$ \\
\hline 1 & $\mathbf{k W}$ & $\mathbf{k W}$ & $\mathbf{k W}$ & $\mathbf{k W}$ & $\mathbf{k W}$ & $\mathbf{k W}$ & $\mathbf{k W}$ & Kvar & $\mathbf{k W}$ & Kvar \\
\hline 2 & 80.4 & 100.4 & 200.8 & 99.7 & 99.7 & 199.4 & 190.9 & 65.0 & 158.1 & 0.41 \\
\hline 3 & 39.5 & 19.3 & 58.8 & 39.4 & 19.3 & 58.7 & 58.4 & 16.2 & 29.1 & 0.19 \\
\hline 4 & 77.8 & 77.8 & 155.6 & 77.3 & 77.4 & 154.7 & 154.0 & 44.6 & 122.9 & -0.05 \\
\hline 5 & 89.7 & 92.9 & 182.6 & 89.0 & 92.2 & 181.2 & 179.3 & 58.9 & 147.6 & 0.16 \\
\hline 6 & 92.9 & 92.9 & 185.8 & 92.2 & 92.2 & 184.4 & 184.2 & 62.2 & 153.5 & 0.26 \\
\hline
\end{tabular}

TABLE VII

THE POWER OF THREE-PHASE GRID CONNECTED PV SYSTEM, LOAD SIMULATION 2

From Table VI, when the high-intensity power on the STC conditions (Ir\&T No 1: $1,000 \mathrm{~W} / \mathrm{m}^{2}, 25{ }^{\circ} \mathrm{C}$ ) is applied on both PV arrays, power produced by each PV array is $100.4 \mathrm{~kW}$, so that the total resources both PV array is $200.8 \mathrm{~kW}$. Power produced by both the dc-dc boost converter is slightly lower than the power produced by the PV array, $99.7 \mathrm{~kW}$, so that the total power both the dc-dc boost converter is $199.4 \mathrm{~kW}$. Active power $\left(P_{i n v}\right)$, which is produced by the three phase NPC inverter board, is lower than dc-dc boost converter, around $190.9 \mathrm{~kW}$, while the reactive power $\left(Q_{i n v}\right)$ is $65 \mathrm{kVAr}$. On the low power intensity condition, PV array 1 received irradiance of $400 \mathrm{~W} / \mathrm{m}^{2}$ and temperature $25{ }^{\circ} \mathrm{C}$ and PV array 2 received irradiance of $200 \mathrm{~W} / \mathrm{m}^{2}$ and temperature $25{ }^{\circ} \mathrm{C}$, power produced by the PV array are $19.3 \mathrm{~kW}$ and $39.5 \mathrm{~kW}$, so that the total resources both $\mathrm{PV}$ array reaching $58.8 \mathrm{~kW}$. Power produced by both the dc-dc boost converter is slightly lower 
than the power that is produced by the PV array, around 39.4 $\mathrm{kW}$ and $19.3 \mathrm{~kW}$. Active power $\left(P_{\text {inv }}\right)$ which is produced by the three phase NPC inverter board is lower than the power produced by the dc-dc boost converter, amounting $58.4 \mathrm{~kW}$. While the reactive power $\left(Q_{i n v}\right)$ which is produced by the three phase NPC inverter board is $16.2 \mathrm{kVAr}$. When the highintensity power condition on both PV array received similar irradiance of $1,000 \mathrm{~W} / \mathrm{m}^{2}$ but at higher temperatures $50^{\circ} \mathrm{C}$, power produced by each PVarray is the same as much as $92.9 \mathrm{~kW}$. It is lower than the STC conditions. Load simulation 2 also has relative similar power characteristics.

When the high-intensity power on the STC condition applied on both PV array, active power is injected into the grid $(P+)$ about $158.1 \mathrm{~kW}$. This is because the load power only needs small enough of $30 \mathrm{~kW}$. Active power generated by the inverter board is $190.9 \mathrm{~kW}$, so that the advantages of the active power given to the grid while the reactive power is injected into the grid $\left(Q^{+}\right)$very small around $0.41 \mathrm{kVAr}$. This is because in a series of filter does not use the capacitor components. Different with the load simulation 2 on Table VII, active power which is injected into the grid $(P+)$ is smaller than the load simulation 1 , around $101.3 \mathrm{~kW}$ due to larger loads from the load simulation $1(90 \mathrm{~kW})$. Active power generated by the inverter board is $192.1 \mathrm{~kW}$, so that the active power given to the grid is smaller, while the reactive power required by the load, absorbed from the grid $(Q-)$ is very small $(-0.12 \mathrm{kVAr})$. So when the low power increases in load simulation 1 , active power and reactive power that is injacted into the grid $\left(P^{+}\right.$and $\left.\mathrm{Q}^{+}\right)$is also low. In the load simulation 2, active power and reactive power absorbed from the grid $(P$ and Q-).

From Table VI and Table VII, power produced by the dcdc boost converter and three-phase NPC inverter is a little lower than by the PV array power production. This declining was caused by some power loss that occurred during the conversion process. Conductive loss is very depended on the power that produced, while switching loss does not depend on the power that produced, because the switching loss can still happen despite the zero power production. Switching loss depends on the switching frequency. Various loss during the conversion process will affect the efficiency and the power produced by the converter. Therefore, efficiency is the best way to measure the performance of the system [11].

The efficiency of the dc-dc boost converter, the efficiency of the inverter NPC three phases and the efficiency of the total system in the load simulation 1 and load simulation are presented on Table VIII and Table IX.

From Table VIII, when the high-intensity power on the STC conditions $\left(1,000 \mathrm{~W} / \mathrm{m}^{2}, 25{ }^{\circ} \mathrm{C}\right)$ is applied on both PV array, the efficiency of the dc-dc boost converter is high, around $99.33 \%$. At the low-intensity power, the efficiency of the dc-dc boost converter is very high, around $99.78 \%$. With various irradiance and temperature conditions, load simulation 2 shows similar characteristics, where the higher power is produced. The efficiency of the dc-dc boost converter will be progressively decrease. For a variety of operating conditions in this simulation, dc-dc boost converter has efficiency in over 99\%. The efficiency of the dcdc boost converter is high because the ratio of the resistance in the inductor $R L$ against the resistif load $(R),(R L / R)$ is very small, by an average of 0.002 . The smaller ratio of $R L / R$, efficiency $(\eta)$ will be higher, as stated in (11) [11].

$$
\eta=\frac{1}{1+\frac{R_{L}}{(1-D)^{2} \cdot R}}
$$

TABLE VIII

THE EFFICIENCY OF THREE-PHASE GRID CONNECTED PV SYSTEM, LOAD SIMULATION 1

\begin{tabular}{|c|c|c|c|c|c|c|c|}
\hline $\begin{array}{c}\text { Ir } \\
\mathbf{\&}\end{array}$ & $\begin{array}{c}\mathbf{P} \\
\mathbf{P V}\end{array}$ & $\begin{array}{c}\mathbf{P} \\
\text { boost }\end{array}$ & $\begin{array}{c}\text { Eff. } \\
\text { Boost }\end{array}$ & $\begin{array}{c}\mathbf{P} \\
\mathbf{i n v}\end{array}$ & $\begin{array}{c}\mathbf{Q} \\
\mathbf{i n v}\end{array}$ & $\begin{array}{c}\text { Eff. } \\
\text { Inv }\end{array}$ & $\begin{array}{c}\text { Eff. } \\
\text { Tot }\end{array}$ \\
\cline { 2 - 7 } $\mathbf{k W}$ & $\mathbf{k W}$ & $\mathbf{\%}$ & $\mathbf{k W}$ & $\mathbf{k v a r}$ & $\mathbf{\%}$ & $\mathbf{\%}$ \\
\hline 1 & 200.8 & 199.4 & 99.33 & 190.9 & 65.0 & 95.72 & 95.08 \\
\hline 2 & 140.1 & 139.3 & 99.52 & 138.8 & 40.0 & 99.61 & 99.13 \\
\hline 3 & 58.8 & 58.7 & 99.78 & 58.4 & 16.2 & 99.40 & 99.18 \\
\hline 4 & 155.6 & 154.7 & 99.43 & 154.0 & 44.6 & 99.58 & 99.01 \\
\hline 5 & 182.6 & 181.2 & 99.29 & 179.3 & 58.9 & 98.91 & 98.20 \\
\hline 6 & 185.8 & 184.4 & 99.26 & 184.2 & 62.2 & 99.85 & 99.11 \\
\hline
\end{tabular}

TABLE IX

THE EFFICIENCY OF THREE-PHASE GRID CONNECTED PV SYSTEM, LOAD SIMULATION 2

\begin{tabular}{|c|c|c|c|c|c|c|c|}
\hline $\begin{array}{l}\text { Ir } \\
\&\end{array}$ & $\begin{array}{c}\mathbf{P} \\
\mathbf{P V}\end{array}$ & $\begin{array}{c}\mathbf{P} \\
\text { Boost }\end{array}$ & $\begin{array}{c}\text { Eff. } \\
\text { Boost }\end{array}$ & $\begin{array}{c}\text { P } \\
\text { Inv }\end{array}$ & $\begin{array}{c}\mathbf{Q} \\
\mathbf{I n v}\end{array}$ & $\begin{array}{l}\text { Eff. } \\
\text { Inv }\end{array}$ & $\begin{array}{l}\text { Eff. } \\
\text { Tot }\end{array}$ \\
\hline $\mathbf{T}$ & KW & KW & $\%$ & KW & Kvar & $\%$ & $\%$ \\
\hline 1 & 200.8 & 199.4 & 99.33 & 192.1 & 83.7 & 96.33 & 95.68 \\
\hline 2 & 140.1 & $\begin{array}{l}139.3 \\
\end{array}$ & 99.52 & 138.1 & 56.2 & 99.10 & 98.62 \\
\hline 3 & 58.9 & 58.7 & 99.76 & 58.6 & 33.5 & 99.68 & 99.44 \\
\hline 4 & 155.6 & 154.7 & 99.43 & 153.1 & 61.4 & 98.96 & 98.39 \\
\hline 5 & 182.6 & $\begin{array}{l}181.2 \\
\end{array}$ & \begin{tabular}{|c|}
99.29 \\
\end{tabular} & 180.1 & $\begin{array}{l}74.3 \\
\end{array}$ & 99.34 & 98.63 \\
\hline 6 & 185.8 & 184.4 & 99.26 & 183.8 & 78.6 & 99.65 & 98.91 \\
\hline
\end{tabular}

The NPC inverter efficiency also has similar characteristics, but lower than the dc-dc boost converter efficiency. The NPC inverter efficiency at high-intensity power on the STC conditions is $95.72 \%$, while in the low intensity power is $99.4 \%$. The efficiency of the total system at high intensity power on the STC conditions is $95.08 \%$.

\section{The Performance of Three-Phase Three-Level NPC Inverter}

The control system on the NPC inverter produces efficiently power flow with ac voltage in phase to grid, also to balance the average power that is sent from the PV array to grid. To produce ac current, inverter transforms dc input to ac output with set duty cycle (D) on a pair of switching components. The duty cycle setting can be done over the dc input voltage $V_{d c}$ which is high enough and greater than the ac peak voltage $V_{a c}$ on the grid. In this simulation, dc input voltage on the NPC inverter is set $500 \mathrm{Vdc}$, and ac voltage on the grid of 260 Vac. To produce the ac current in phase with the grid voltage, grid current is measured and arranged so that always similar with the reference current from the dc voltage regulator $\left(I_{\text {grid }}=I_{\text {ref }}\right)$. To balance the average power flow from the PV array to the grid, the dc voltage regulator is set to bus dc voltage equal with dc voltage reference $\left(V_{d c b u s}=V_{d c r e f}\right)[11]$. 
The simulation results of the control system performance of the inverter showed that the three-level three-phase NPC inverter has worked well to produce a sinusoidal three-phase current, $I_{a b c}$ with little ripple that is in phase with the sinusoidal three-phase three-level voltage, $V_{a b c}$ for each phase in output inverter, where the dc input voltage of $500 V_{d c}$ was converted into the output voltage phase to phase 260 Vac. This is shown in Fig. 17 and Fig. 18.

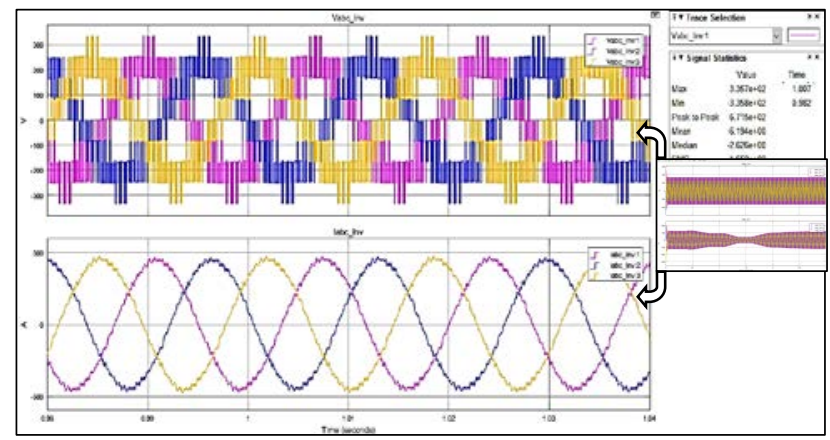

Fig. 17 Current in phase with voltage on the inverter.

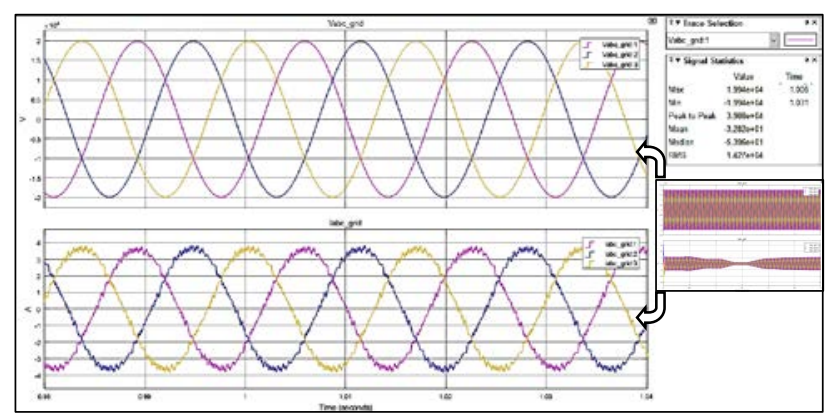

Fig. 18 Current in phase with voltage on the bus grid.

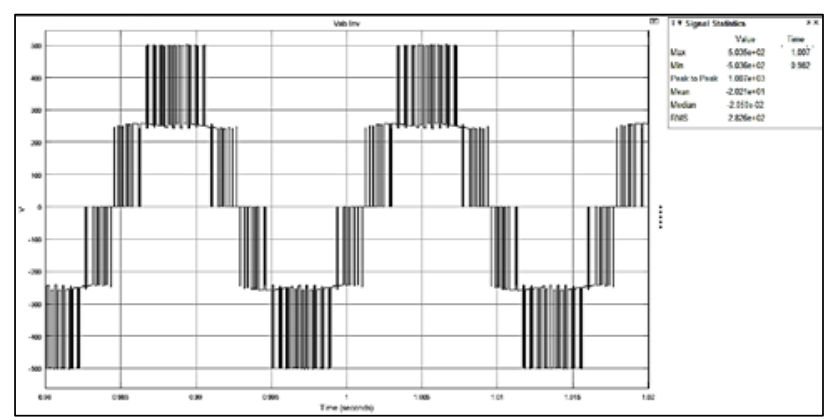

Fig. 19 Three-level output voltage of NPC inverter.

It is also shown on the bus grid that produces sinusoidal three-phase current $\left(I_{a b c}\right)$ with little ripple in phase with sinusoidal three-phase voltage $\left(V_{a b c}\right)$ for any phase on the bus grid $25 \mathrm{kV}$ ( $V_{\text {rms }}$ phase to neutral $\left.=14 \mathrm{kV}\right)$. This is shown in Fig. 18. For different load conditions, there is no influence on the inverter performance.

A three-level output voltage produced by the NPC inverter is to minimize the harmonic distortion [12]. The phase to phase voltage of the inverter output voltage waveform derived from the NPC three-level voltage of $\pm 500 \mathrm{~V}, \pm 250 \mathrm{~V}$, and $0 \mathrm{~V}$. A three-level voltage follows a sinusoidal waveform generated from a dc input voltage which is modulated by the frequency modulation index $(\mathrm{mf}=33)$ and the conversion rate $(\mathrm{M})$, the amount of $-1 \mathrm{M}(\mathrm{D})$ up to $+1 \mathrm{M}(\mathrm{D})$, where $\mathrm{M}(\mathrm{D})=2 \mathrm{D}-1$. Average number of NPC inverter output voltage level in accordance with the number of capacitors used in the dc bus which is two, where the number of voltage levels, $\mathrm{m}$, as $\mathrm{m}=\mathrm{k}$ +1 with $\mathrm{k}$ is the number of capacitors. So that the number of voltage levels, m, is a three-level [13], as shown in Fig. 19.

The instantaneous inverter output current, $i_{a c}(t)$, which is in phase with the instantaneous grid voltage, $v_{a c}(t)$, is obtained when active grid current, Id_grid, is equal to the active reference current, id_ref, from the dc voltage regulator (Id_grid=Id_ref) [11]. The reactive current (Iq reference_ref) is set to zero to maintain unity power factor as shown in Fig. 20, where id_grid always synchronizes with the id_ref in various operating conditions.

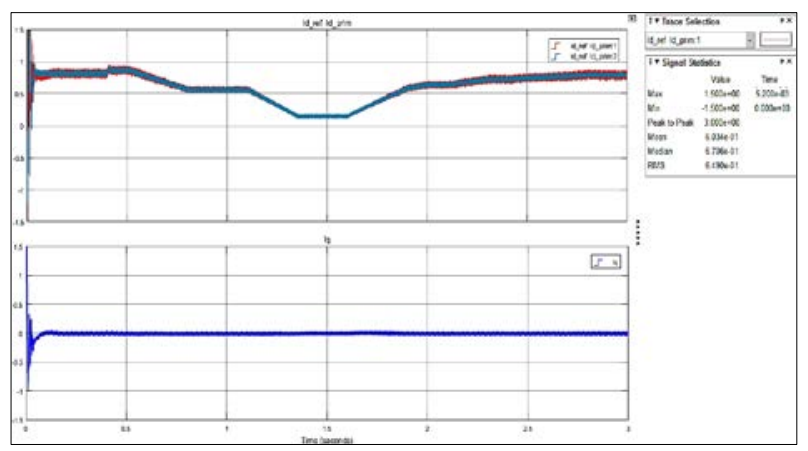

Fig. 20 Synchronization of the instantaneous inverter current with instantaneous grid voltage.

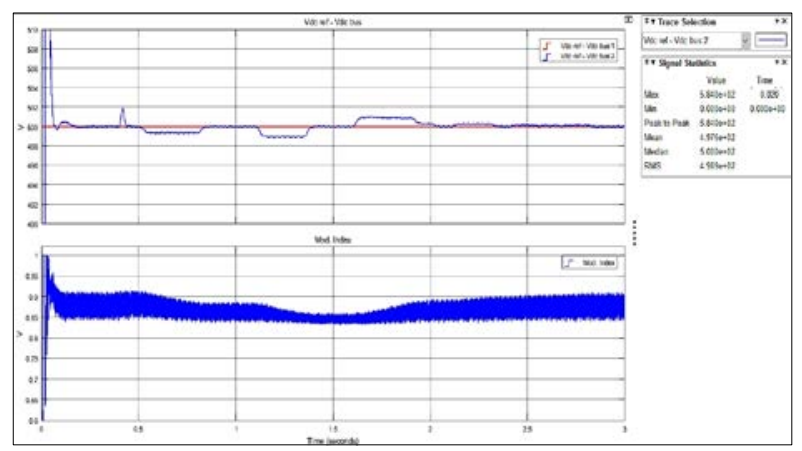

Fig. 21 Synchronization of the dc bus voltage and dc reference voltage.

To balance the average injected power from the PV array to the grid, the voltage on the dc bus (Vdc_bus) is measured and compared with dc voltage reference $\left(V d c \_r e f=500 \mathrm{~V}\right)$. The difference between measured dc bus voltage and dc voltage reference (Vdc_bus - Vdc_ref) is the error signal that is used as a feedback on the dc voltage regulator. If the error signal is positive, then dc voltage regulator will increase the active current reference id_ref, and if the error signal is negative, dc voltage regulator will reduce the active current reference id_ref. In the inverter control system, the active current reference id_ref is automatically set to the measured dc bus voltage with dc voltage reference $\left(V d c \_b u s=V d c \_r e f\right)$ or signal error is zero when the steady state is reached. $V d c \_b u s=V d c \_r e f$ and the active current reference id_ref is set automatically. The average power that is sent to the grid is 
expected proportional with the power produced by the PV array $\left(P_{a c} \approx P_{P V}\right)[11]$ as shown in Fig. 21.

\section{E. The Power Quality of Grid Connected PV System}

Power quality problem due to the inverter board must meet the grid standard. The international standard for grid power quality requirements has been specified in IEEE1547, EN61000-3-2, and IEC61727. Power factor produced by the inverter board is restricted minimum 0.90 on the condition of the raising of $50 \%$ of nominal power PV array. The THD current injected into the grid is limited at maximum 5\% while THD voltage is not restricted, but must be made as low as possible in order to meet the power factor standard [7].

The power quality parameters, that are measured at both the inverter output and on the grid bus are power factor, THD current and voltage. Power factor is calculated in accordance with (12) [16].

$$
P F=\frac{P_{a c}}{V_{r m s} \times I_{r m s}}=\frac{P_{a c}}{S}
$$

The power quality of the NPC inverter board or on the grid bus in various irradiances and temperatures conditions in two scenarios (load simulation 1 and simulation load 2) are presented in Table X and Table XI.

TABLE X

THE POWER QUALITY OF THREE-PHASE GRID CONNECTED PV SySTEM, LOAD SIMULATION 1

\begin{tabular}{|c|c|c|c|c|c|c|c|c|c|c|}
\hline$\&$ & $\begin{array}{c}\mathbf{P} \\
\text { inv }\end{array}$ & \begin{tabular}{c|} 
S \\
Inv
\end{tabular} & PF & $\begin{array}{c}\text { THD I } \\
\text { Inv }\end{array}$ & $\begin{array}{c}\text { THD V } \\
\text { Inv }\end{array}$ & \begin{tabular}{|c|}
$\mathbf{P}$ \\
grid \\
\end{tabular} & \begin{tabular}{|c|} 
S \\
Grid \\
\end{tabular} & $\begin{array}{l}\mathbf{P F} \\
\text { arid }\end{array}$ & \begin{tabular}{|c|} 
THD I \\
grid \\
\end{tabular} & $\begin{array}{c}\text { THD V } \\
\text { grid }\end{array}$ \\
\hline $\mathbf{T}$ & $\mathbf{k W}$ & kVA & & $\%$ & $\%$ & $\mathbf{k W}$ & kVA & & $\%$ & $\%$ \\
\hline 1 & 190.9 & 224.4 & 0.85 & 3 & 39 & 158.1 & 166.2 & 0.95 & 3 & 0 \\
\hline 2 & 138.8 & 202.8 & 0.68 & 3 & 40 & 109.1 & 149.0 & 0.73 & 4 & 0 \\
\hline 3 & 58.4 & 17.1 & 0.33 & 8 & 41 & \begin{tabular}{|l|}
29.1 \\
\end{tabular} & 128.9 & 0.23 & 14 & 0 \\
\hline 4 & 154.0 & 164.5 & 0.94 & 3 & 40 & 122.9 & 126.8 & 0.97 & 4 & 0 \\
\hline 5 & 179.3 & 182.7 & 0.98 & 3 & 40 & \begin{tabular}{|l|l}
147.6 \\
\end{tabular} & 149.2 & 0.99 & 3 & 0 \\
\hline 6 & 184.2 & 18.5 & 0.98 & 3 & 40 & 153.5 & 154.9 & \begin{tabular}{|l|l|}
0.99 \\
\end{tabular} & 3 & 0 \\
\hline
\end{tabular}

TABLE XI

THE POWER QUALITY OF THREE-PHASE GRID CONNECTED PV SYSTEM, LOAD SIMULATION 2

\begin{tabular}{|c|c|c|c|c|c|c|c|c|c|c|}
\hline Ir & \multirow{2}{*}{$\begin{array}{c}\text { P } \\
\text { inv }\end{array}$} & \multirow{2}{*}{$\begin{array}{c}\text { Inv } \\
\text { T }\end{array}$} & \multirow{2}{*}{$\begin{array}{c}\text { PF } \\
\text { inv }\end{array}$} & $\begin{array}{c}\text { THD I } \\
\text { Inv }\end{array}$ & $\begin{array}{c}\text { THD V } \\
\text { inv }\end{array}$ & $\begin{array}{c}\text { P } \\
\text { grid }\end{array}$ & $\begin{array}{c}\text { S } \\
\text { grid }\end{array}$ & \multirow{2}{*}{$\begin{array}{c}\text { PF } \\
\text { grid }\end{array}$} & $\begin{array}{c}\text { THD I } \\
\text { grid }\end{array}$ & $\begin{array}{c}\text { THD V } \\
\text { grid }\end{array}$ \\
\hline 1 & 192.1 & 259.4 & 0.74 & 3 & 39 & 101.3 & 149.1 & 0.68 & 4 & 0 \\
\hline 2 & 138.1 & 224.4 & 0.62 & 4 & 40 & 52.2 & 117.6 & 0.44 & 9 & 0 \\
\hline 3 & 58.6 & 194.5 & 0.30 & 10 & 41 & -27.7 & 98.2 & -0.28 & 18 & 0 \\
\hline 4 & 153.1 & 179.6 & 0.85 & 4 & 39 & 66.0 & 87.1 & 0.76 & 7 & 0 \\
\hline 5 & 180.1 & 184.1 & 0.98 & 3 & 39 & 90.6 & 91.8 & 0.99 & 5 & 0 \\
\hline 6 & 183.8 & 187.5 & 0.98 & 3 & 39 & 96.6 & 97.8 & 0.99 & 5 & 0 \\
\hline
\end{tabular}

From Table X, when the high intensity power (No.1) on the STC condition was applied on both PV arrays, THD current inverter is 3\% (according to the IEEE standard, maximum 5\%), and THD voltage inverter was 39\%, so that the power factor was 0.85 (still under the standard 0.9). In the low intensity power condition (No.3), THD current inverter was 8\% (above standards required), and THD voltage inverter increased $41 \%$, so that the power factor was worse at 0.33 . In load simulation 1 , power quality standards required (minimum 0.9 ) start at PV array return to high intensity power, where at the moment
THD of inverter current is low of $3 \%$ and THD of inverter voltage is relatively remained at $40 \%$, so that the power factor is 0.94 . The highest power factor is 0.98 . While the power quality in the load simulation 2, looks slightly worse than the load simulation 1 . This is because of the difference in number, type, and load imbalance. The measurement of power factor that is presented in this research in accordance with technical guidelines of commercial inverter that does not guarantee power quality standards, if the active power production under $25 \%$ of nominal power [17].

The power quality on the grid bus, the grid voltage was not look distorted, where the THD grid voltage always constant at $0 \%$ while THD grid current change influenced by the irradiance level, the amount and type of the load and the value of the capacitor in a series of filters, $C_{f}$. If $C_{f}$ is small, THD current into the grid will increase [18]. This is shown by the simulation results where the THD current into the grid is relatively higher than the THD current produced by inverter, because in the simulation did not use a series capacitor filter.

\section{CONCLUSION}

Topology of multistring converter of three-phase $200 \mathrm{~kW}$ PV power plant system grid-connected which was designed in this research had high performance in various operating conditions. This due to more power generated by the NPC inverter (> $190 \mathrm{~kW})$ at high power generation on the STC conditions $\left(1,000 \mathrm{~W} / \mathrm{m}^{2}, 25{ }^{\circ} \mathrm{C}\right)$. This multistring converter topology was designed using two dc-dc boost multistring converters connected in parallel to a centralized of three-phase three-level NPC inverter with the size of the string was shorter and more parallel strings as well as the maximum voltage of the PV array of $273.5 \mathrm{~V}$ closed to dc voltage reference $500 \mathrm{~V}$. Each dc-dc boost multistring converter has individual MPPT controllers. The total system had lowest efficiency of $95.08 \%$ at high power generation and the highest efficiency of $99.4 \%$ at low power generation. The power quality generated in accordance with the requirements of grid, as well as the inverter injected more active power and less reactive power to the grid. However, the inverter response slightly worse for greater reactive power and unbalanced load, so it needs to be further research as well as the use of the inverter with a higher voltage level and the use of capacitor in a filter circuit.

\section{REFERENCE}

[1] Bo Yuan, $\mathrm{Xu}$ at that, Donghao $\mathrm{Li}$, and Zhaoan Wang, "A new architecture for high fouling maximum power point tracking in gridconnected engineering system," IEEE 6th International Power Electronics and Motion Control Conference, 2009. IPEMC '09, vol. 10, Wuhan, May 17-20 May 2009, pp. 2504 - 2121.

[2] H. AbdEl-Gawad and Vijay K. Sood, "Overview of connection topologies for grid-connected PV systems," Canadian Conference on Electrical and Computer Engineering (CCECE), 2014 IEEE 27th, Toronto, ON, 2014, pp. 1 - 8.

[3] Chaiyant Boonmee, Pakorn Somboonkit, and Napat Watjanatepin, "Performance comparison of three-level and multi-level for Gridconnected engineering systems,"'" 12th International Conference on Electrical Engineering/Electronics, Computer, Telecommunications and Information Technology (ECTI-CON), 2015, Hua Hin , 24-27 June 2015, pp. 1 - 5. 
[4] Huiying Zheng, Shuhui Li, and Julio Proano, "PV energy extraction characteristic study under shading conditions for different converter configurations," 2012 IEEE Power and Energy $S^{o C}$ iety General Meeting, San Diego CA, 22-26 July 2012, pp. 1 - 8.

[5] Kwonyub, Hojoon Hyung Shin, Jung-Ik Ha, and Anno Yoo, "Fouling control of multi-string PV system considering switching Add with existing analysis," 2014 IEEE Applied Power Electronics Conference and Exposition - APEC 2014, vol. , Fort Worth, TX , 16-20 March 2014, pp. 3143 - 3149.

[6] Mohammed S. Agamy et al., "Dc-dc converter topology assessment for large scale installation design distributed engineering plant architectures," 2011 IEEE Energy Conversion Congress \& Exposition, Phoenix, AZ , 17-22 Sept. 2011 , pp. 764 - 769 Off-Highway Truck.

[7] S. B. Kjaer, J. K Pedersen, and F Blaabjerg, "A review of single-phase grid-connected inverters for engineering modules," IEEE Transactions on Industry Applications, vol.41, no. 5, pp. 1292-1306 , September 2005.

[8] YongLi Zhu, JianGuo Yao, and at Wu, "Comparative study of two stages and single stage topologies for grid-tie engineering generation by PSCAD/EMTDC," the International Conference on Advanced Power System Automation and Protection (APAP), 2011, vol. 2, Beijing, 16-20 OCt. 2011 , pp. 1710 - 2180.

[9] Santu Kr. Giri, Sarbani Mukherjee, and Subrata Amitava Banerjee, "Split the multistring 3-level NPC inverter engineering suitable for partially shaded conditions," Power India International Conference (PIICON), 2014 6th IEEE, Delhi , 5-7 Dec. 2014 , pp. 1 - 6.

[10] Dorai Yelaverthi Babu and Shyama P Das, "Dual multi-string PV topology fed three level grid connected inverter," 2014 IEEE Applied Power Electronics Conference and Exposition - APEC 2014, Fort Worth, TX , 16-20 March 2014 , pp. 2481 - 1710.

[11] R. W. Erickson and D Maksimovic, Fundamentals of Power Electronics, 2 nd Ed.: Springer, 2000.
[12] P. Sudha Rani, K. V. S Prasadarao, and Koppineni R. N. V Subbarao, "Comparison of symmetrical and asymmetrical multilevel inverter topologies with reduced number of switches," the International Conference on Smart Electric Grid (ISEG), 2014, Thunder, 19-20 Sept. 2014, pp. 1 - 5.

[13] Panagiotis Stergiopoulos Panagis, Fotis, Pantelis Marabeas, and Stefanos Manias, "Comparison of state of the art multilevel inverters," 2008 IEEE Power Electronics Specialists. Conference, Rhodes, 15-19 June 2008, pp. 4296 - 4301.

[14] "Data Sheet Solar Panel SPR-305E-WHT-D The doCument", SunPower Corporation, September 2010.

[15] Gilbert M. Masters, Renewable and Efficient Electric Power Systems, 1 st ed., Gilbert M. Masters, Ed. Hoboken, New Jersey, USA: John Wiley \& Sons, Inc., 2004.

[16] F. Chicco Batrinu, G, J Schlabbach, and F Spertino, "According of gridconnected engineering plant operation on the harmonic distortion," IEEE Mediterranean Electrotechnical Conference MELECON 2006, Malaga, 16-19 May 2006 , pp. 861 - 783.

[17] Pedro A. B. Block et al., "Power Quality Analyses of a large scale installation design Engineering System," 5th International Renewable Energy Congress (IREC), Hammamet, 25-27 March 2014, pp.1- 6.

[18] Sachin Jain and Vivek Agarwal, "A Single-Stage Grid Connected Inverter Topology for Solar PV Systems With Maximum Power Point Tracking," IEEE Transactions on Power Electronics, vol. 22, no. 5, pp. 1928 - 1940 , September 2007. 